一技術報告一

\title{
大麻種子の発芽能力鑑定法
}

桐原美穂，川端三十一

茨城県警察本部刑事部科学捜査研究所

干310-8550 茨城県水戸市笠原町978番地 6

\section{Judgement of Germination Ability of Cannabis Seeds}

\author{
Miho Kirihara and Mitokazu Kawabata \\ Forensic Science Laboratory, Ibaraki Prefectural Police H. Q. \\ 978-6 Kasaharacho, Mito, Ibaraki 310-8550 Japan
}

(Received 18 August 2009; accepted 7 October 2009)

\begin{abstract}
Cannabis seeds not pretreated for prevention of germination are on sale through the Internet in recent years. These seeds are illegal and show a high probability of germination. The number of arrestees, who had cultivated illegal Cannabis seeds, has increased year after year.

Recently, we had an opportunity to examine Cannabis seeds. We carried out experiments for the proof of the germination abilities by usual and embryo-exposure techniques. The embryo-exposure technique is a speedy and effective method for germination of Cannabis seeds, especially for the weakened seeds.

In this study, we have reported and recorded the course of germination, how to determine the germination and the growth process of Cannabis.
\end{abstract}

Key words: Cannabis seeds, Germination, Cultivation, Embyo-exposure technique

\section{緒 言}

平成 20 年，大麻取締法違反で摘発された人員は前 年比 $22 \%$ 増になり，これは統計を取り始めた昭和 31 年以降で過去最高の数字を記録した．初犯者が占め る割合は約 $86 \%$ と高く，20代以下の若年層が全体の $62 \%$ を占める状況である. その中でも，大麻の不正 栽培が社会問題になっている。本来，日本に抢いて 大麻種子は七味唐辛子や医薬品, ペットの慨として 利用されているが，これらは加熱などの方法で発芽
防止処理が施されている。しかし，近年，発芽防止 処理されていない大麻種子がインターネット上で販 売され，平成20年に大麻を栽培して摘発されたのは 前年より $65 \%$ 増の 210 人で, 10 年で約 5 倍まで増 加1)した.

本県に扔いても最近大麻種子を押収し, 大麻種子 の発芽能力鑑定を行ったが, 大麻種子の発芽能力鑑 定についての報告はあまりなく, また, 発芽の詳細 を報告したものも見あたらない。そこで，我々は鑑 定に先立ち, 陽性試料と陰性試料を入手して発芽状 
況や生育状況を記録し, 発芽能力の有無を判断する 段階を求めることとした.さらに大麻種子について 肧露出法を行い鑑定の迅速化を図った．また，鑑定 に際し, 子葉の確認による発芽能力鑑定のみなら ず，大麻を栽培し，大麻の特徵的形態の確認及び大 麻成分の鑑定を求められることがある，その場合， 盗難の危険性や人目にふれない安全な場所を考慮す ると, 実験室内で栽培せざるを得ない。そこで, 実 験室内で大麻を育成した場合の生育過程も明らかに するため，大麻の栽培を行った。本稿では，その発 芽能力鑑定法及び大麻の栽培の記録を報告する.

通常，大麻種子と呼ばれているものは「マシニン」 として日本薬局方2 2 に収載され, 植物学上では果実 に該当するが，ここでは便宜上大麻種子と記載す る.

\section{事例の概要}

ある都道府県警察が大麻取締法における大麻の捜 索中，インターネットで発芽防止処理されていない 大麻種子を販売している会社を突き止めた。その会 社を大麻の栽培幇助で家宅捜索し, 発送伝票やパソ コンを押収した。それらの解析を行うと，購入者は 全国に点在しており，平成15年 3 月 1 日より運用が 開始された参考通報制度により，警察庁を通じ本県 に連絡があった。そして，本県においても大麻種子 を押収し，鑑定に付された。

\section{材料と方法}

\section{1 大麻種子}

\section{（1）陽性試料}

発芽能力のある試料（陽性試料）として，栃木県 農業試験場によって繊維用に開発された「とちぎし ろ」を栃木県より譲渡された. 大麻種子の寿命を保 つため，冷蔵庫で保管し，低湿度にした。

\section{(2) 陰性試料}

発芽能力のない試料（陰性試料）として，株式会 社ペッズイシバシ製，ヤマガラ，中型インコ，八ム スター用の饂の「麻の実」を用いた。

\section{2 器材}

恒温器は yamato 社製 Drying Oven DS600を使用 し，植物育成用蛍光灯は $\mathrm{NEC}$ 製のビオルックス
HG20wを用いた。

\section{3 実験}

（1）通常の方法による発芽能力鑑定

大麻種子を滅菌シャーレ上にのせ， $25^{\circ} \mathrm{C} に$ 設定し た恒温器内で経過観察した.

（2）肧露出法による発芽能力鑑定

肧露出法により，次の方法で果皮を人工的にはが した後，上記 (1)の方法で経過観察した。胚露出法 の方法は，Fig. 1 に示すように

a 大麻種子を妨湯に数分浸し, 果皮を柔ら かくする.

b 果柄の跡を下にし, 滅菌メスで果皮の稜線に 沿って切る.

c 切った部分を指の腹で押し広げ，広げた部分 の内側から果皮を押し，果皮を取る.

という手順で行った.

\section{（3）発芽後の栽培}

発芽までは光を遮断し，その後は植物育成用蛍光 灯の下で育成した。土は滅菌された種まき専用土， 肥料としてハイポネックス活力剂及び開花促進剤を 用いた．水はカビ防止のため精製水を使用した.

\section{（4）大麻種子の呈色試験}

$0.1 \%$ TTC $(2,3,5$-Triphenyl-2H-tetrazolium chloride）水溶液を作製し，この溶液中に肧露出法によ り胚を露出させた種子を入れ，60分間常温にて放置 した. TTC (2,3,5-Triphenyl-2H-tetrazolium chloride）は, 関東化学より購入した.

\section{結果及び考察}

\section{1 発芽}

(1) 通常の方法

実験方法 (1)により発芽試験を行ったところ，2 日目で幼根，4 日目で子葉，5 日目で本葉を確認し た (Fig. 2).

(2) 胚露出法

実験方法(2)により発芽試験を行ったところ，2 日目で子葉，3 日目で本葉を確認した（Fig. 3). 肧 露出法は果皮を人工的にはがすことで鑑定を迅速に するだけではなく，発芽力が弱くなっている種子に も有効な方法であり，本鑑定では，果皮を片方を取 るだけでも十分な効果が得られた。 

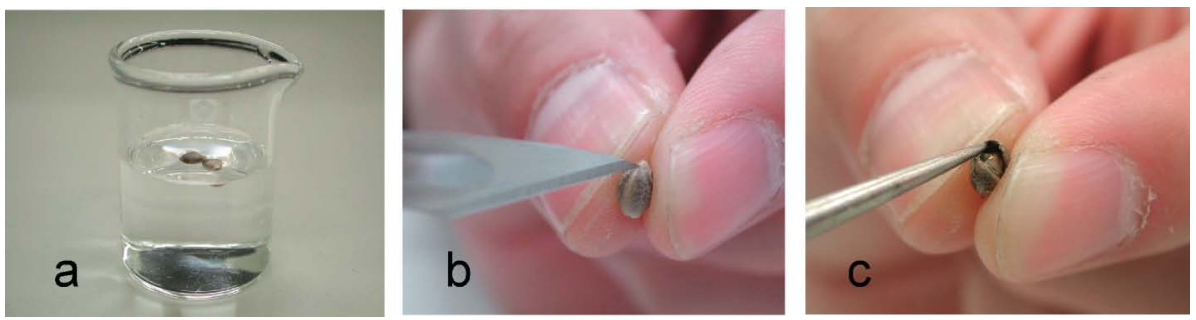

Fig. 1 Embyo-exposure technique.

a: soak seeds in tepid water, b: cut each side of a seed, c: peel a seed case from inside
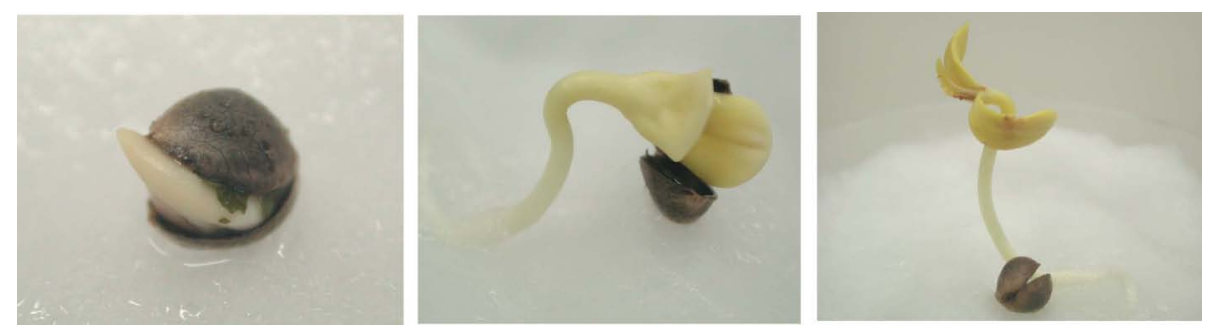

Fig. 2 Germination by usual technique. left: after 2 days, center: after 4 days, right: after 5 days
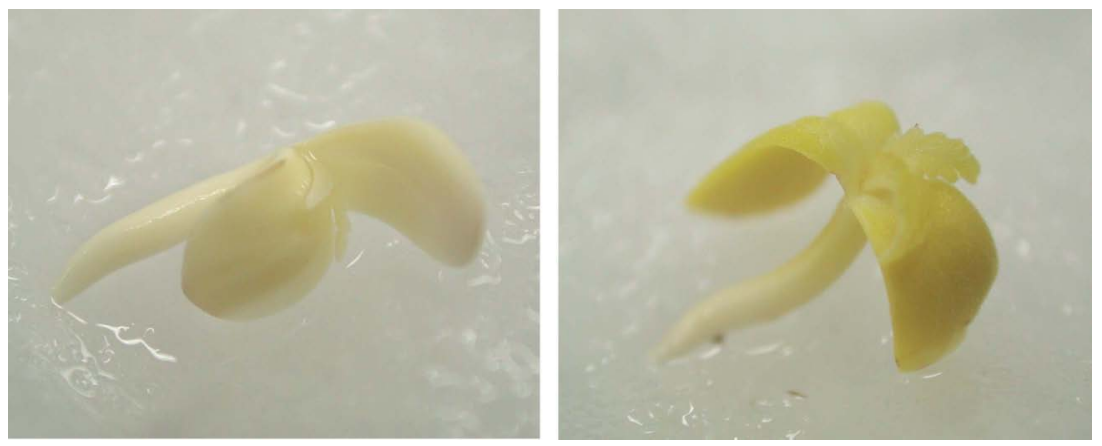

Fig. 3 Germination by embyo - exposure technique. left: after 2 days, right: after 3 days
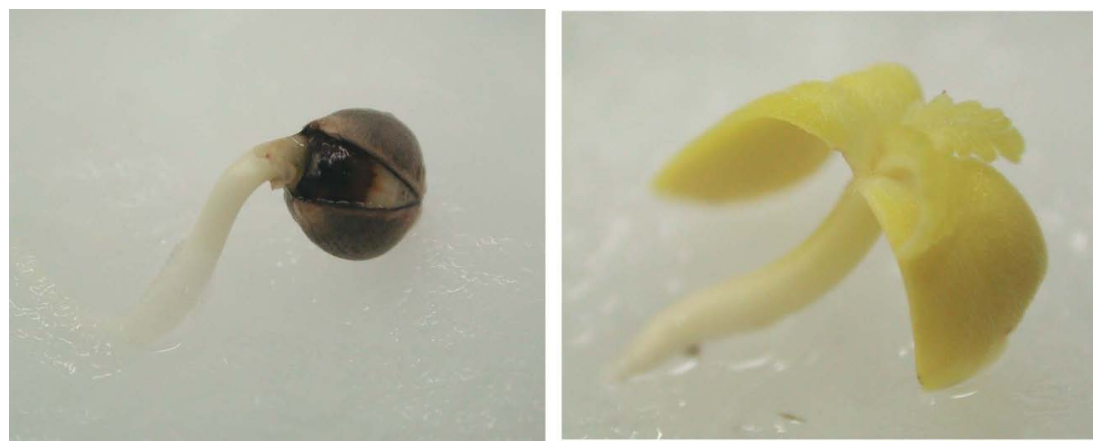

Fig. 4 Comparison between two germination.

left: by usual technique, right: by embyo-exposure technique 
実験 (1) と実験 (2)を比較すると，3 日目の段階で Fig. 4 に示すような差違が見られた. すなわち，実 験 (1)では子葉は確認できず, 実験 (2)では本葉まで 確認できた．このことから，大麻種子の発芽能力鑑 定法に掞いて, 肧露出法は有効な手段と考えられ た。

なお，陰性試料については，実験方法(1)及び (2) によりそれぞれ14日間発芽能力鑑定を行ったが，い ずれの方法でも幼根は確認できず，発芽は認められ なかった。

\section{2 栽培}

実験方法 (3)により栽培を行った。 8 日目で約 7 $\mathrm{cm}, 1$ ケ月後約 $15 \mathrm{~cm}, 2$ 个月後約 $50 \mathrm{~cm}, 3$ ケ月後 約 $1 \mathrm{~m}, 4$ ヶ月後約 $1 \mathrm{~m} 35 \mathrm{~cm}, 5$ ヶ月後約 $1 \mathrm{~m} 80$ $\mathrm{cm}, 6$ ヶ月後約 $2 \mathrm{~m}$ に生長した (Fig. $5 \mathrm{a} \sim \mathrm{g}$ ).

植物に光をあて, 生長を促す目的の照明器具に は, メタルハライドランプ, 高圧ナトリウムラン プ，蛍光灯などがあるが，今回は設備費及び電気代 が最も安価な植物育成用蛍光灯を用いた。植物は昼 と夜の時間の長さの変化を感じて花を開花させる. 短い夜で開花する長日植物, 長い夜で開花する短日 植物, 夜の長さに関係なく開花する中日植物がある が，大麻は短日植物に分類される．播種から 3 ヶ月 後，短日処理を開始した．短日処理とはその性質を 利用し，蛍光灯の光をあてる時間を短くすること で, 強制的に開花させることができる，そして，播 種から 4 ヶ月後雄花（Fig. 5, h） が開花した. 短日 処理には，先に雄花が反応し花を開花させる.

本実験の結果により，約 1 ヶ月後の段階で大麻の 特徵的形態及び大麻成分の検出が鑑定可能と思われ た。雌株か雄株かを明らかにする場合には，少なく とも 4 ヶ月以上の栽培期間が必要であるとわかっ た.

\section{3 植物育成用蛍光灯の効果}

植物育成用蛍光灯の有無が大麻の生長に与える影 響を調べた。植物育成用蛍光灯の下で生育させた大 麻と日当たりの良い室内において生育させた大麻で は, Fig. 6 に示すように, 約 3 ヶ月後の段階で約 2 倍の生長の差が見られた。実験室レベルでは, 植物 育成用蛍光灯でも十分な効果があるとわかった．植 物育成用蛍光灯を使用することは, 大麻の特徵的形
態及び大麻成分を検出するをでの鑑定期間を短縮す る意味でも大きな役割を果たすと考えられた。

\section{4 予試験法}

大麻種子の発芽能力鑑定の予試験として, 国立医 薬品食品衛生研究所の緒方らが TTC を用いた大麻 種子の呈色試験について報告4)している.

その方法では肧を粉砕して用いているが，今回は 呈色反応後の発芽能力確認のため, 肧露出法で肧を 露出させた種子を用いて実験 3(4)の通り行った. そして，陽性試料及び陰性試料で呈色試験を行った ところ，陽性試料は呈色（赤色）を確認した。赤色 の呈色は，発芽能力を有することを示す4).さら に，その呈色した大麻種子を滅菌シャーレ上にの せ，呈色反応後の発芽試験を行った．結果を Fig. 7 に示す. 通常の大麻種子の発芽経過に比べ生長は劣 ったが，呈色反応後の大麻種子でも子葉を確認する ことは可能であった．このことは，TTCによる呈 色試験は発芽能力に大きな影響を及ぼさないと考え られ，大麻種子の発芽能力の予試験に有用と考えら れる。なお，陰性試料については，実験の結果，赤 色の呈色は確認されなかった。

\section{5 発芽能力鑑定法における発芽の判断}

発芽能力鑑定では，どの段階をもって発芽能力が あると認めるかの明確な規定はない。そこで, 本県 に抢ける大麻種子の発芽能力鑑定では，子葉を確認 して発芽能力を認めるとした. Fig. 8-right では幼 根が出現したように見えるが，水分を吸収したこと による種子の膨張によるもので，発芽とは認めな い. Fig. 8-left のような子葉を確認して発芽を認め るとすることは，鑑定における時間的な制約もある が，大麻が 1 属 1 種 3 )であることが大きな根拠とな っている。

なお，本事例の鑑定資料については，押収時冷蔵 庫に保管してあった種子は発芽能力を認めたものが 多く，室内にそのまま放置してあった種子などで保 管状態が悪かったものはほとんど発芽しなかった。 種子の発芽力を保つには，保管状況が大きく関係し ていると思われた。 また，通常の方法で一定期間の 発芽能力鑑定を行ったものの発芽が見られなかった 種子を胚露出法で鑑定したところ，発芽が見られた ものもあった．以上のことから，発芽能力鑑定にお 

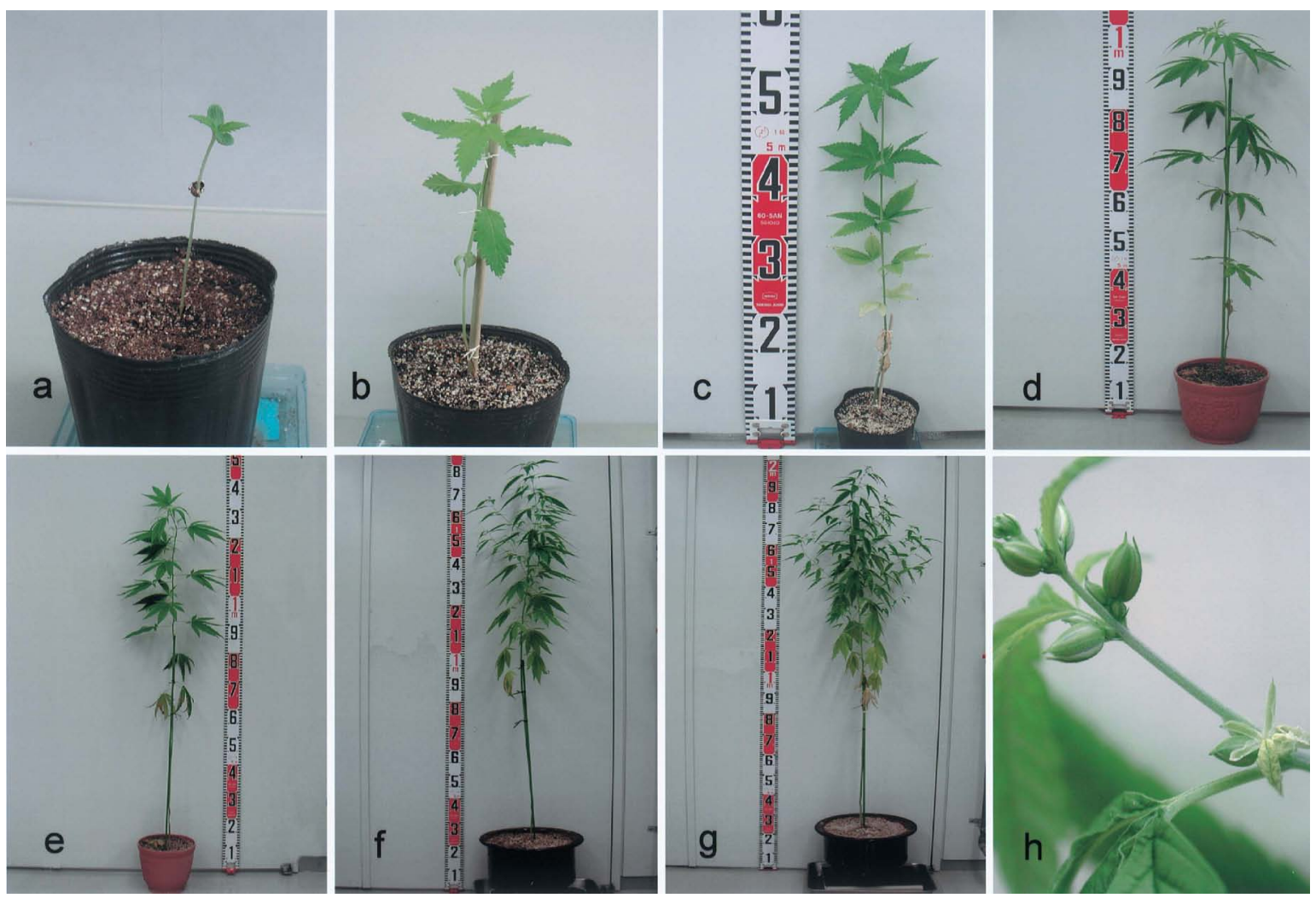

Fig. 5 Cultivation of Cannabis.

a: after 8 days, b: after 1 month, c: after 2 months, d: after 3 months, e: after 4 months, f: after 5 months, g: after 6 months, f: male flower

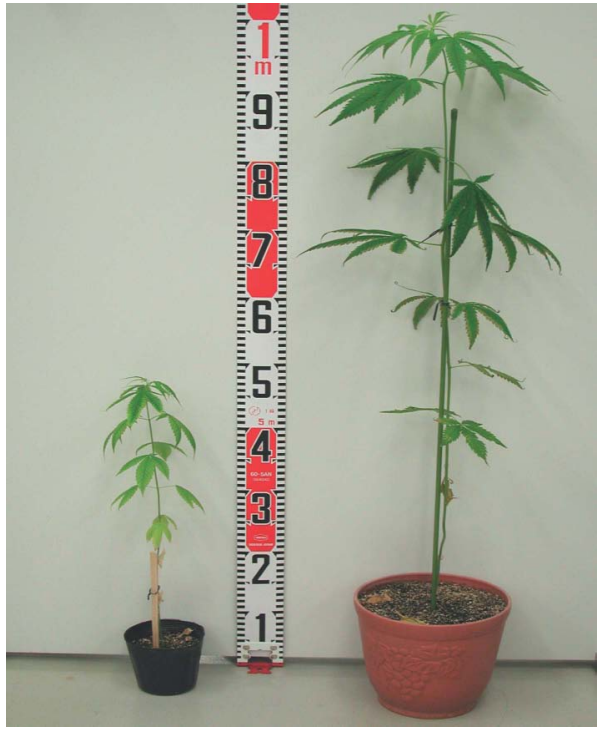

Fig. 6 Difference in growth under two light sources.

left: under natural light, right: using fluorescent plant grow light

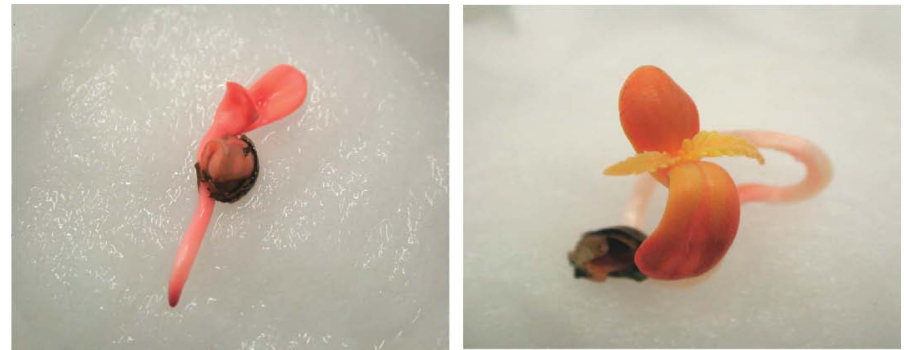

Fig. 7 Germination test after color reaction. left: after 3 days, right: after 7 days
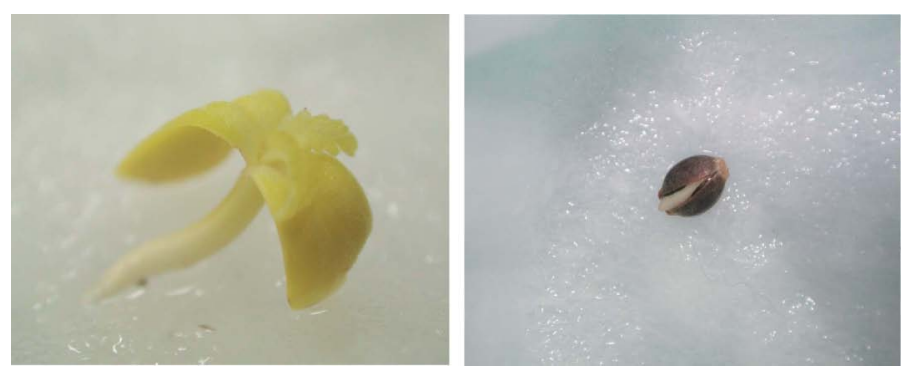

Fig. 8 Germination ability. left: presence, right: absence 
いては通常の方法と肧露出法を併用することが最も 有効と考えられた.

\section{文 献}

\section{参 考}

今回の大麻種子の発芽能力鑑定及び大麻「とちぎ しろ」の栽培は, 大麻研究者免許に基づいて行っ た。

\section{謝 辞}

本鑑定を行うにあたり，ご指導下さいました東京 都薬用植物園の吉澤政夫氏,「とちぎしろ」を譲渡 して下さいました栃木県農業試験場に深く感謝いた します。
1）黑瀬義孝編：BAN 情報発信. BAN，5，46 (2009).

2）日本薬局方解説書編集委員会編：第十五改正日 本薬局方解説書. 医薬品各条生薬等, D-649-D650 ，廣川書店，東京（2006）。

3）大津留修 : 大麻のいわゆる一属一種問題をめぐ る最近の裁判例. 科警研報告, 28, 11-14 (1986).

4）緒方 潤, 花尻（木倉）瑠理, 吉松嘉代, 木内 文之，合田幸広：大麻種子の 2,3,5-Triphenyl2H-tetrazolium chloride (TTC) による発芽能力 鑑定法. 薬学雑誌, 128, 1707-1711 (2008). 